\title{
Bacterial Purification of Sewage Wastewater Effluents and its Influence on Germination Indices of Vigna radiata and Hordeum vulgare
}

\author{
Ashraf M. Essa ${ }^{1,2}$, Khaled E. El-Gayar ${ }^{1,3 *}$, Mohamed N. Awad ${ }^{1}$, Majed Al-Shaeri ${ }^{4}$, \\ Mohamed Abdel Salam ${ }^{5}$, Hassien M. Alnashiri ${ }^{1}$ \\ ${ }^{1}$ Biology Department, Faculty of Science, Jazan University, Saudi Arabia \\ ${ }^{2}$ Botany Department, Faculty of Science, Fayoum University, Fayoum, Egypt \\ ${ }^{3}$ The Holding Company for Biological Products and Vaccines (VACSERA), Egypt \\ ${ }^{4}$ Department of Biological Sciences, Faculty of Science, King Abdulaziz University, Saudi Arabia \\ ${ }^{5}$ Chemistry Department, Faculty of Sciences, King Abdulaziz University, Saudi Arabia
}

Received: 24 March 2018

Accepted: 22 June 2018

\begin{abstract}
Excessive exposure to heavy metals is known to induce deleterious effects on health. The monitoring of heavy metals in sewage is important for examining environmental pollution induced by treated sewage effluent (TSE). In the current investigation, heavy metals concentrations of TSE of two sewage treatment plants in the Jazan region of KSA were monitored using a Perkin Elmer Optima 7000 DV inductively coupled plasma optical emission spectrometer (ICP-OES). The heavy metals concentrations were below the permissible limit, according to the Ministry of Water and Electricity (MWE) standards of Saudi authorities, except for magnesium and mercury. TSE from the treatment plants was subjected to additional treatment using the volatile organic compounds (VOCs) of the bacterial strain Citrobacter freundii. A marked reduction of the heavy metals concentrations of the bacterial-treated TSE was recorded. The impact of the bacterial-treated TSE on germination indices of Vigna radiata and Hordeum vulgare was investigated. The seedlings irrigated with the bacterial-treated TSE recorded a clear enhancement of growth parameters. Moreover, the level of accumulated heavy metals in seedlings irrigated with bacterial-treated TSE was reduced compared with those irrigated with untreated TSE. The current study clarified that the level of heavy metals in TSE could be markedly reduced via the application of bacterial VOCs and hence it can be used as a water resource for agricultural purposes.
\end{abstract}

Keywords: Citrobacter freundii, sewage wastewater, heavy metals, Hordeum vulgare, Vigna radiate

*e-mail:k_elgayar@yahoo.com 


\section{Introduction}

Water is an integral part of our lives [1-2]. Environmental pollution-associated problems are a main interest of society. Environmental laws are given general applicability and their fulfillment has been stricter. So, regarding health, environment and economy, the war against pollution has become a main matter. The relative severity of the quality of water varies among countries according to population growth, the scope of manufacturing quality of non-renewable water resources, economic status and institutional capacity. The input ingredients of domestic and urbanized water resource are pathogens, nutrients, salts, oxygendemanding materials, and suspended solids. Overall, agrarian drains receive the volume of the treated and untreated municipal pollution loading [3]. Wastewater is defined as the flow of utilized water separate from industries, homes and commercial activities that are directed to treatment plants by a plan pipes network. This wastewater is furthermore assorted according to its sources of origin as industrial and municipal wastewater [4].

Parameters of wastewater treatment effect the formation of complex microbial structures and species composition. The biomass structure determines metabolic pathways that may happen in the technological system and the treated water quality [5-6]. Wastewater treatment is achieved by four basic methods: mechanical, physical, chemical, and biological. The activated sludge process is one of the most significant treatment systems based on the preservation of a complex microbial biomass able to degrade, absorb and adsorb the organic matter found in wastewater. Anaerobic processes are most applied in the treatment of biological sludge and industrial wastewater $[1,4]$. This sludge causes dangerous problems due to its toxicity and quantity. The effective bioconversion process to treat the wastewater sludge involves potential microbial activities [7-8]. Wastewater treatment processes and disinfection systems do not inactivate the whole microbial population; the surviving microorganisms can adapt to the conditions in the distribution system and start multiplying [9]. Anthropogenic activities like mining, processes of metallurgy and other chemical industries lead to the discharge of a variety of pollutants into the environment that cause serious problems to the environment and human health. In developing countries, careless fulfillment of laws and lack of an economic method for industrial waste management have caused rising pollution of water sources. Various chemical and physical techniques have been applied to reduce the hazardous effects of these pollutants [10-15].

Reuse of wastewater is an integral part of water demand management, promoting the protection of highquality fresh water and reducing both environmental pollution and overall supply costs. Recent outgrowth in technology and changes in behavior to wastewater reuse suggest that there is an effort for wastewater reuse in the developing world [16-17]. The use of wastewater has many benefits, including increased crop yields and decreased dependence on chemical fertilizers in addition to low cost [18]. Some local farmers in the western region of Saudi Arabia use treated and untreated wastewater for the irrigation of vegetable crops under no regulation [19]. Wastewater is considered a source of organic matter and nutrients for plants. Nevertheless, it may contain unwanted chemicals and pathogens that have environmental and health risks. Also, some materials present in wastewater can decrease soil productivity. Finally, leakage of wastewater to aquifers may cause pollution with pathogens and organic matters $[17,19]$. The purpose of the current study was to investigate the impact of TSE treated with bacterial VOCs on germination indices of some crop plant seedlings.

\section{Materials and Methods}

\section{Sewage Wastewater Samples}

The treated domestic wastewater samples were gathered from Jazan and Ahad- Almsareha wastewater treatment plants in Jazan, KSA. Wastewater samples were subjected to some physical analyses, including $\mathrm{pH}$ and electric conductivity.

\section{Isolation of Bacteria and Culture Conditions}

Some bacterial strains were applied in this study, Pseudomonas putida, Citrobacter freundii and Serratia liquefaciens, Enterobacter sp., and Escherichia coli that were isolated from sewage wastewater in Jazan, Saudi Arabia [20]. Cultures were routinely grown aerobically in nutrient broth medium and incubated at $37^{\circ} \mathrm{C}$ for $24 \mathrm{~h}$ with shaking. The bacterial strains were screened for the production of volatile thiols and amines, according to [21], and Citrobacter freundii was chosen for the current study due to its capability to produce high concentrations of VOCs.

\section{Treatment of Sewage Wastewater with VOCs of Citrobacter freundii}

Treated sewage wastewater samples were exposed to the culture off-gases released during the aerobic growth of Citrobacter freundii using an aerobic bioreactor consisting of two chambers [22]. The first chamber contained one liter of Citrobacter freundii culture at mid-log phase $(\mathrm{O} . \mathrm{D} \approx 0.6)$ that was grown aerobically at $37^{\circ} \mathrm{C}$ for $24 \mathrm{~h}$. The other chamber contained wastewater samples and received the bacterial VOCs for $48 \mathrm{hrs}$ through a $0.2 \mu \mathrm{m}$ filter (Millipore) to avoid any bacterial contamination. The treated wastewater samples exposed to bacterial VOCs were centrifuged at $12000 \mathrm{rpm}$ for 10 minutes and the supernatant were collected in order to: i) analyze heavy metals concentration and ii) to study 
their impact on germination indices of Vigna radiata and Hordeum vulgare.

\section{Plant Materials and Treatments}

Mung bean (Vigna radiata; Fabaceae) seeds and barley (Hordeum vulgare; Poaceae) grains were surfaces sterilized by immersion in $70 \%$ ethanol for 2 min followed by rinsing with sterilized de-ionized water three times, 5 minutes each. Twenty surfaces sterilized seeds or grains were sown in each pot at $5 \mathrm{~mm}$ depth. Three replicate pots were used for each treatment and watered regularly to retain the soil at field capacity. The pots were randomly distributed at $25^{\circ} \mathrm{C}$ for two weeks. The treatments were carried out as follows: Control: irrigated with sterilized $\mathrm{dH}_{2} \mathrm{O}, \mathrm{JWW}$ : irrigated with Jazan sewage wastewater, TJWW: irrigated with Jazan sewage wastewater treated with VOCs of Citrobacter freundii, AWW: irrigated with Ahd-Almasarha sewage wastewater, and TAWW: irrigated with Ahd-Almasarha sewage wastewater treated with VOCs of Citrobacter freundii.

\section{Analysis of Plant Growth Parameters}

In order to investigate the impact of TSE and TSE treated with bacterial VOCs on germination indices of Vigna radiata and Hordeum vulgare, the percentage of germinated seeds or grains, length of seedlings, fresh weight and dry weight of seedlings were determined [23].

\section{Plant Sample Digestion}

Nitric-perchloric acid digestion of plant samples was carried out according to the procedure recommended by the AOAC [24]. One gram of sample was placed in a $250 \mathrm{ml}$ digestion tube and $10 \mathrm{ml}$ of concentrated $\mathrm{HNO}_{3}$ was added. The mixture was boiled gently for $30-45 \mathrm{~min}$. After cooling, $5 \mathrm{ml}$ of $70 \% \mathrm{HClO}_{4}$ was added and the mixture was boiled gently until dense white fumes appeared. After cooling, $20 \mathrm{ml}$ of distilled water was added and the mixture was boiled further to release any fumes. The solution was cooled and filtered through Whatman No. 42 filter paper. The filtrate was then transferred quantitatively into $25 \mathrm{ml}$ volumetric flasks by adding $\mathrm{dH}_{2} \mathrm{O}$ and kept for further analysis.

\section{Heavy Metals Analysis}

Sewage wastewater samples and bacterial-treated samples were conserved by the addition of $1 \mathrm{ml}$ concentrated $\mathrm{HNO}_{3}$ to $\mathrm{pH}$ of 2.7-3.0. Samples were analyzed for cadmium $(\mathrm{Cd})$, lead $(\mathrm{Pb})$, mercury $(\mathrm{Hg})$, arsenic (As), silver (Ag), chromium $(\mathrm{Cr})$, aluminum (Al), cobalt $(\mathrm{Co})$, nickel $(\mathrm{Ni})$, manganese $(\mathrm{Mn})$, magnesium $(\mathrm{Mg})$, zinc $(\mathrm{Zn})$, copper $(\mathrm{Cu})$, and iron $(\mathrm{Fe})$ using a Perkin Elmer Optima 7000 DV inductively coupled plasma optical emission spectrometer (ICP-OES; Perkin-Elmer Corporation, Norwalk, CT). Regarding the analysis of heavy metals in the digested plant tissues, the digested plant samples were analyzed for the heavy metals mentioned above. The readings were taken from the equipment and the results were converted to actual concentration of metals in the samples using the equation;

Heavy metals conc. $(\mu \mathrm{g} / \mathrm{g})$

Extract vol.

Reading x sample wt.

Table 1. Heavy metals analysis of sewage wastewater treated and untreated with volatile organic compounds of Citrobacter freundii.

\begin{tabular}{|c|c|c|c|c|c|}
\hline \multirow{2}{*}{ Metals } & \multicolumn{5}{|c|}{ Concentration (ppm) } \\
\cline { 2 - 6 } & JWW & TJWW & AWW & TAWW & MWE Standard \\
\hline Cadmium & $0.008 \pm 0.004$ & BDL & BDL & BDL & 0.010 \\
\hline Lead & $0.031 \pm 0.007$ & BDL & $0.020 \pm 0.014$ & BDL & 0.100 \\
\hline Mercury & BDL & BDL & $0.006 \pm 0.002$ & BDL & 0.001 \\
\hline Arsenic & $0.007 \pm 0.003$ & $0.006 \pm 0.013$ & $0.004 \pm 0.002$ & BDL & 0.100 \\
\hline Silver & BDL & BDL & BDL & BDL & 0.500 \\
\hline Chromium & BDL & BDL & BDL & BDL & 0.100 \\
\hline Aluminum & $0.258 \pm 0.003$ & $0.056 \pm 0.003$ & $0.046 \pm 0.000$ & $0.006 \pm 0.003$ & 5.000 \\
\hline Cobalt & $0.009 \pm 0.001$ & $0.004 \pm 0.002$ & $0.011 \pm 0.003$ & $0.008 \pm 0.002$ & 0.050 \\
\hline Nickel & $0.012 \pm 0.003$ & BDL & $0.008 \pm 0.001$ & BDL & 0.200 \\
\hline Manganese & $0.157 \pm 0.002$ & $0.045 \pm 0.002$ & $0.104 \pm 0.001$ & $0.016 \pm 0.003$ & 0.200 \\
\hline Magnesium & $80.061 \pm 0.632$ & $74.851 \pm 1.344$ & $9.902 \pm 0.034$ & $9.302 \pm 0.631$ & 50.00 \\
\hline Zinc & $0.235 \pm 0.003$ & $0.006 \pm 0.001$ & $0.206 \pm 0.002$ & $0.005 \pm 0.001$ & 4.000 \\
\hline Copper & $0.016 \pm 0.002$ & BDL & $0.014 \pm 0.003$ & BDL & 0.400 \\
\hline Iron & $0.035 \pm 0.006$ & $0.005 \pm 0.004$ & $0.034 \pm 0.000$ & $0.003 \pm 0.001$ & 5.000 \\
\hline
\end{tabular}

JWW: Jazan wastewater; TJWW: VOCs treated Jazan wastewater; AWW: Ahd-Almsareha wastewater;

TAWW: VOCs Treated Ahd-Almsareha wastewater; MWE: Ministry of Water and Electricity; BDL: below detection limit 
Table 2. Effect of sewage wastewater treated with VOCs of Citrobacter freundii on percentage of seed germination of Vigna radiate and Hordeum vulgare.

\begin{tabular}{|c|c|c|c|c|}
\hline \multirow{2}{*}{ Treatment } & \multicolumn{4}{|c|}{ Seed germination of Vigna radiata } \\
\hline & $3^{\text {rd day }}$ & $4^{\text {th }}$ day & $5^{\text {th }}$ day & $6^{\text {th }}$ day \\
\hline $\mathrm{H}_{2} \mathrm{O}$ & 33.3 & 72.6 & 88.3 & 100 \\
\hline JWW & 33.3 & 72.1 & 85.3 & 100 \\
\hline TJWW & 22.2 & 65.6 & 81.7 & 96.4 \\
\hline AWW & 31.3 & 78.1 & 93.6 & 100 \\
\hline TAWW & 34.8 & 79.3 & 95.8 & 100 \\
\hline \multirow{2}{*}{ Treatment } & \multicolumn{4}{|c|}{ Grain germination of Hordeum vulgare } \\
\hline & $3^{\text {rd day }}$ & $4^{\text {th }}$ day & $5^{\text {th }}$ day & $6^{\text {th }}$ day \\
\hline $\mathrm{H}_{2} \mathrm{O}$ & 33.7 & 65.7 & 88.9 & 100 \\
\hline JWW & 35.4 & 64.6 & 86.3 & 100 \\
\hline TJWW & 33.0 & 63.1 & 83.5 & 100 \\
\hline AWW & 41.5 & 67.7 & 95.7 & 100 \\
\hline TAWW & 39.6 & 68.5 & 96.4 & 100 \\
\hline
\end{tabular}

JWW: Jazan wastewater; TJWW: Jazan wastewater treated with C. freundii; AWW: Ahd-Almsareha wastewater;

TAWW: Ahd-Almsareha wastewater treated with $C$. freundii

\section{Statistical Analysis}

The data existing in the present investigation are the mean value of at least three replicates. MS Excel 2007 was used to calculate standard errors.

\section{Results and Discussion}

The gap between water supply and demand is widening and has reached alarming scales. Sewage wastewater treatment plants are planned to convert raw wastewater to a liquid outlet with standard criteria, and that can be discharged safely into water bodies without negative influences on the environment. The treated sewage wastewater could be applied for agricultural purposes since it contains various macronutrients and micronutrients. The application of treated sewage effluents in agriculture may compensate for the shortage of water resources and diminish the eutrophication process through decreasing the discharge of nutrients into water bodies [25-26]. Simultaneously, the application of treated sewage effluent for agricultural uses has various impacts on soil, such as carbon and nitrogen content, the structure of microbial communities, levels of $\mathrm{Ca}$ and $\mathrm{Mg}$, and accumulation of heavy metals [27].

The sewage wastewater of Jazan and Ahd-Almsareha treatment plants recorded $\mathrm{pH}$ values of $7.05,8.15,6.81$ and 7.98 for JWW, TJWW, AWW, TAWW; respectively. Meanwhile, the electrical conductivity values were 1730, 1166, 323, $186 \mathrm{mg} / \mathrm{L}$ for JWW, TJWW, AWW, and TAWW, respectively. Data in Table 1 demonstrate the heavy metals concentrations in the treated and untreated wastewater. In comparison with Ministry of Water and Electricity (MWE) standards in Saudi Arabia [28], most analyzed metals were found at levels below the permissible limits - except for magnesium in Jazan sewage $(80.061 \mathrm{ppm})$ and mercury in Ahd-Almsareha sewage $(0.006 \mathrm{ppm})$ that were above the MWE standards. The occurrence of heavy metals in sewage wastewater is one of the major reasons for water and soil pollution. In fact, domestic effluents have low levels of heavy metals. Nevertheless, the discarding of industrial effluents to domestic wastewater treatment plants could result in the rise of heavy metal concentrations in the sewage effluent. The existence of various heavy metals such as $\mathrm{Pb}, \mathrm{Zn}, \mathrm{Cd}, \mathrm{B}, \mathrm{Cr}, \mathrm{Cu}, \mathrm{Fe}$, and $\mathrm{Hg}$ was shown at various levels in the treated sewage effluents collected from some sewage treatment plants in Oman [29]. In the same way, the existence of a wide range of heavy metals at different concentrations in the wastewater from the Biological Wastewater Treatment Plant in Brazil was seen [30].

Regarding sewage wastewater treated with the volatile organic compounds of $C$. freundii, the levels of most heavy metals were reduced at different degrees except of magnesium in Jazan sewage that was found at a concentration (74.851 ppm) higher than the maximum limit according to MWE. The reduction of heavy metals concentration in TSE treated with the bacterial VOCs could be assigned to the presence of some volatile chelators in the bacterial VOCs that could be involved in the immobilization of the soluble metal ions. These results are in harmony of our previous study that highlighted the capability of Escherichia coli Z3 to reduce the toxicity of various 

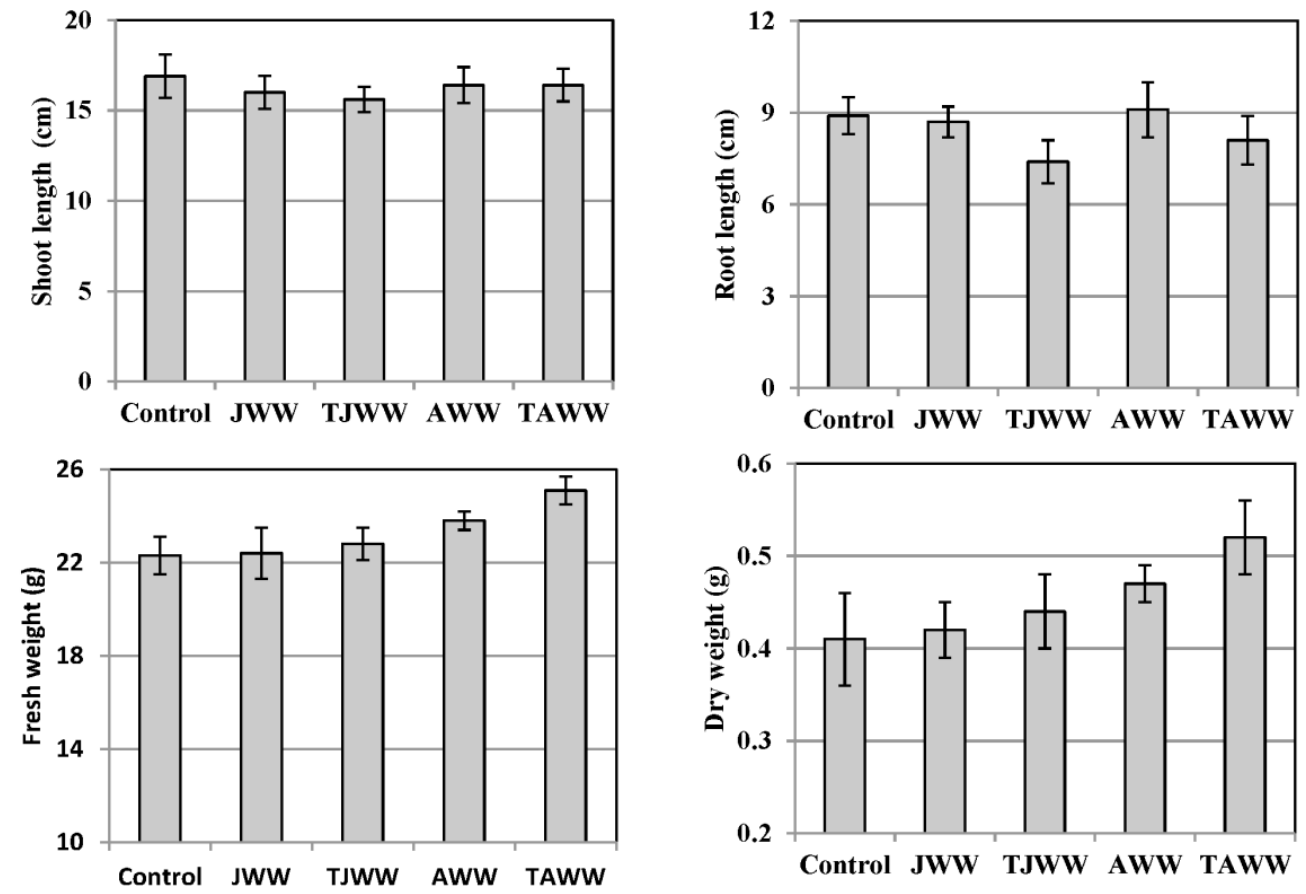

Fig. 1. Growth parameters of Vigna radiata seedlings irrigated with sewage wastewater treated with VOCs of Citrobacter freundii for 21 days - JWW: Jazan wastewater; TJWW: Jazan wastewater treated with C. freundii; AWW: Ahd-Almsareha wastewater; TAWW: AhdAlmsareha wastewater treated with C. freundii

heavy metals indirectly through the release of volatile biogases, including hydrogen sulfide, organothiols, nitrogenous compounds, and ammonia [15]. These compounds play a principal role in the transformation of metals into metal precipitates via various mechanisms [21, 31-33].

Results in Table 2 demonstrated the impact of the sewage wastewater from Jazan and Ahd-Almsareha
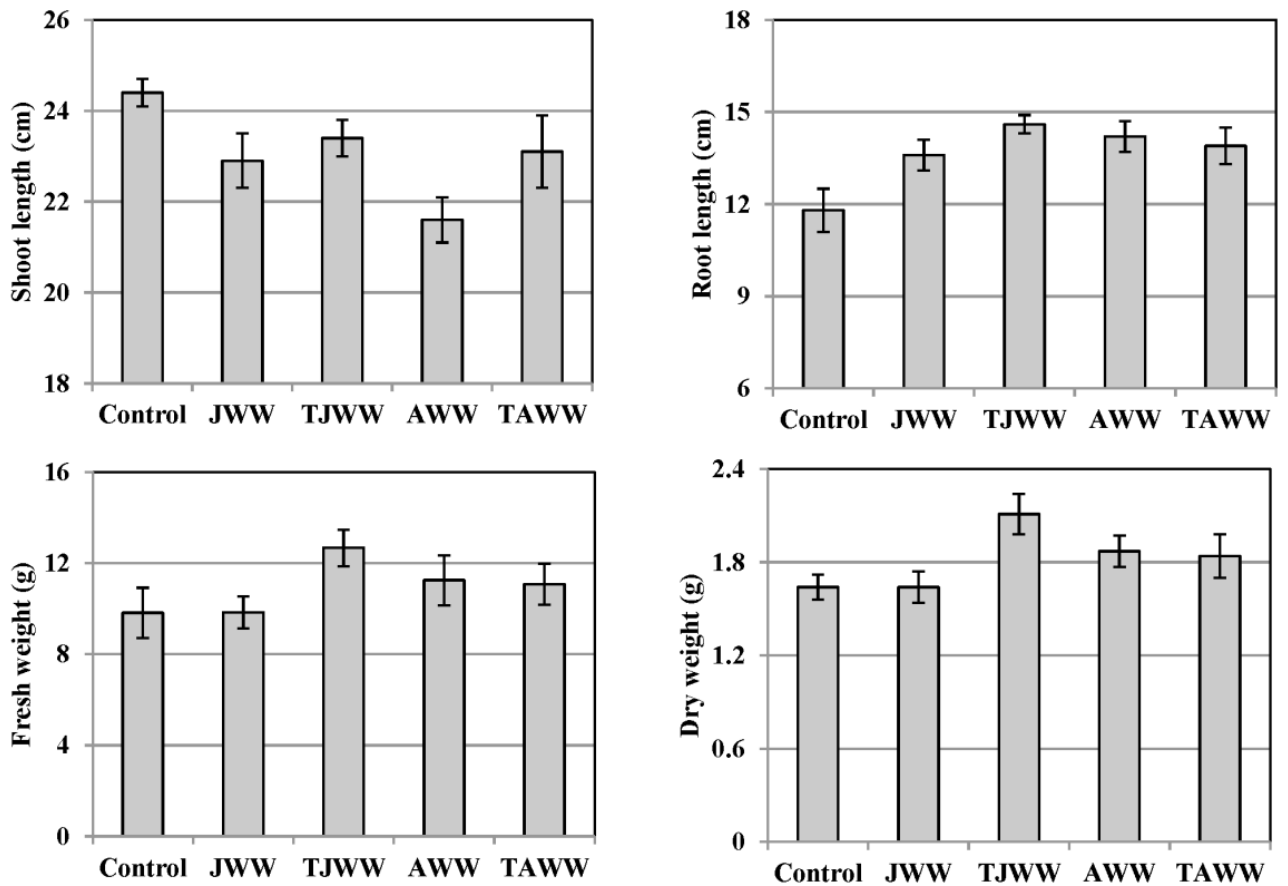

Fig. 2. Growth parameters of Hordeum vulgare seedlings irrigated with sewage wastewater treated with VOCs of Citrobacter freundiifor 21days - JWW: Jazan wastewater; TJWW: Jazan wastewater treated with C. freundii; AWW: Ahd-Almsareha wastewater; TAWW: AhdAlmsareha wastewater treated with C. freundii 
Table 3. Analysis of heavy metals in Vigna radiate and Hordeum vulgare seedlings irrigated with sewage wastewater treated and untreated with volatile organic compounds of Citrobacter freundii.

\begin{tabular}{|c|c|c|c|c|c|}
\hline \multirow{2}{*}{ Metal } & \multicolumn{5}{|c|}{ Metal concentrations in Vigna radiate seedlings (ppm) } \\
\hline & Control & JWW & TJWW & AWW & TAWW \\
\hline Cadmium & $0.020 \pm 0.005$ & $0.032 \pm 0.005$ & $0.019 \pm 0.017$ & $0.029 \pm 0.002$ & $0.011 \pm 0.019$ \\
\hline Lead & $0.051 \pm 0.002$ & $0.064 \pm 0.008$ & $0.041 \pm 0.007$ & $0.118 \pm 0.006$ & $0.073 \pm 0.011$ \\
\hline Mercury & BDL & BDL & BDL & BDL & BDL \\
\hline Arsenic & $0.001 \pm 0.011$ & $0.031 \pm 0.001$ & $0.008 \pm 0.003$ & $0.030 \pm 0.001$ & $0.011 \pm 0.002$ \\
\hline Silver & $0.006 \pm 0.190$ & $1.471 \pm 0.520$ & $0.346 \pm 0.121$ & $1.030 \pm 0.621$ & $0.541 \pm 1.168$ \\
\hline Chromium & $0.001 \pm 0.009$ & BDL & BDL & BDL & BDL \\
\hline Aluminum & BDL & BDL & BDL & BDL & BDL \\
\hline Cobalt & $0.009 \pm 0.004$ & $0.011 \pm 0.001$ & BDL & BDL & BDL \\
\hline Nickel & $0.024 \pm 0.003$ & $0.032 \pm 0.001$ & $0.015 \pm 0.002$ & $0.030 \pm 0.001$ & $0.023 \pm 0.001$ \\
\hline Manganese & $0.112 \pm 0.006$ & $0.277 \pm 0.003$ & $0.193 \pm 0.004$ & $0.192 \pm 0.004$ & $0.135 \pm 0.002$ \\
\hline Magnesium & $10.611 \pm 0.042$ & $16.732 \pm 0.491$ & $13.883 \pm 0.220$ & $19.754 \pm 0.722$ & $10.843 \pm 0.424$ \\
\hline Zinc & $0.249 \pm 0.001$ & $0.337 \pm 0.002$ & $0.252 \pm 0.002$ & $0.350 \pm 0.003$ & $0.244 \pm 0.005$ \\
\hline Copper & $0.055 \pm 0.008$ & $0.102 \pm 0.001$ & $0.007 \pm 0.001$ & $0.127 \pm 0.008$ & $0.104 \pm 0.000$ \\
\hline Iron & $0.300 \pm 0.002$ & $0.336 \pm 0.000$ & $0.148 \pm 0.005$ & $0.599 \pm 0.003$ & $0.244 \pm 0.002$ \\
\hline \multirow{2}{*}{ Metal } & \multicolumn{5}{|c|}{ Metal concentrations in Hordeum vulgare seedlings (ppm) } \\
\hline & Control & JWW & TJWW & AWW & TAWW \\
\hline Cadmium & BDL & BDL & BDL & BDL & $\mathrm{BDL}$ \\
\hline Lead & $0.071 \pm 0.004$ & $0.048 \pm 0.002$ & $0.015 \pm 0.002$ & $0.013 \pm 0.001$ & $0.001 \pm 0.000$ \\
\hline Mercury & BDL & BDL & BDL & BDL & BDL \\
\hline Arsenic & BDL & $\mathrm{BDL}$ & BDL & BDL & $\mathrm{BDL}$ \\
\hline Silver & $0.002 \pm 0.286$ & $0.894 \pm 0.139$ & $0.620 \pm 0.159$ & $1.158 \pm 0.092$ & $0.703 \pm 0.271$ \\
\hline Chromium & BDL & $\mathrm{BDL}$ & $\mathrm{BDL}$ & BDL & $\mathrm{BDL}$ \\
\hline Aluminum & $\mathrm{BDL}$ & $0.020 \pm 0.003$ & $0.022 \pm 0.001$ & $0.067 \pm 0.002$ & $0.071 \pm 0.001$ \\
\hline Cobalt & $0.014 \pm 0.003$ & $0.023 \pm 0.003$ & $0.014 \pm 0.004$ & $0.008 \pm 0.001$ & $0.006 \pm 0.003$ \\
\hline Nickel & $0.018 \pm 0.002$ & $0.025 \pm 0.001$ & $0.010 \pm 0.002$ & $0.013 \pm 0.005$ & $0.008 \pm 0.004$ \\
\hline Manganese & $0.101 \pm 0.001$ & $0.098 \pm 0.001$ & $0.089 \pm 0.001$ & $0.059 \pm 0.004$ & $0.056 \pm 0.001$ \\
\hline Magnesium & $9.480 \pm 0.173$ & $8.297 \pm 0.059$ & $6.583 \pm 0.004$ & $5.466 \pm 0.002$ & $5.130 \pm 0.029$ \\
\hline Zinc & $0.247 \pm 0.005$ & $0.223 \pm 0.002$ & $0.205 \pm 0.004$ & $0.235 \pm 0.003$ & $0.170 \pm 0.004$ \\
\hline Copper & $0.139 \pm 0.002$ & $0.107 \pm 0.004$ & $0.018 \pm 0.001$ & $0.112 \pm 0.002$ & $0.064 \pm 0.003$ \\
\hline Iron & $0.284 \pm 0.003$ & $0.570 \pm 0.002$ & $0.553 \pm 0.004$ & $0.688 \pm 0.005$ & $0.649 \pm 0.005$ \\
\hline
\end{tabular}

JWW: Jazan wastewater; TJWW: Jazan wastewater treated with C. freundii; AWW: Ahd-Almsareha wastewater;

TAWW: Ahd-Almsareha wastewater treated with $C$. freundii; BDL: below detection limit

stations before and after treatment with the VOCs of C. freundii on the germination of Vigna radiate seeds and Hordeum vulgare grains. The percentage of seed germination of $V$. radiate and $H$. vulgare using Jazan wastewater was quite similar to those treated with $\mathrm{dH}_{2} \mathrm{O}$. Meanwhile, the treated and untreated wastewater of Ahd-Almsareha station marginally enhanced the germination of both plant seeds. The influence of sewage wastewater of Jazan and Ahd-Almsareha stations before and after treatment with VOCs of $C$. freundii on the growth parameters of $V$. radiata and $H$. vulgare seedlings was demonstrated in Figs 1-2. Overall, the treated and untreated wastewater of Jazan and AhdAlmsareha stations showed a non-significant difference in shoot and root lengths of $V$. radiate irrigated with wastewater in comparison to control seedlings. In the 
meantime, the shoot length of $H$. vulgare seedlings irrigated with treated or untreated wastewater of both stations was slightly decreased while the root length was enhanced in the seedlings irrigated with treated or untreated wastewater of both stations. Moreover, the fresh and dry weight of $V$. radiata and $H$. vulgare were markedly increased in the seedlings irrigated with Jazan and Ahd-Almsareha wastewater. The maximum dry weight $(13.9 \mathrm{mg})$ of $V$. radiate was recorded in the seedlings irrigated with treated wastewater of Ahd-Almsareha stations, while $H$. vulgare seedlings demonstrated their maximum dry weight $(15.6 \mathrm{mg})$ when treated with Ahd-Almsareha wastewater. The enhancement of seedling growth could be attributed to the presence of macronutrients such as nitrogen, phosphorus, and potassium in the treated wastewater. The obtained results showed the presence of high $\mathrm{N}$ and $\mathrm{P}$ content in the treated sewage water (unpublished data). Typically, treated wastewater effluents contain various levels of macronutrients such nitrogen, phosphorus, and potassium in addition to the micronutrients $(\mathrm{Ca}, \mathrm{Mg}, \mathrm{B}$, $\mathrm{Mg}, \mathrm{Fe}, \mathrm{Mn}$ or $\mathrm{Zn}$ ) that are required for plant growth [34]. Comparable results were proven to improve crop yield as a result of the application of wastewater for irrigation [35-36].

The results presented in Table 3 demonstrate the concentrations of metals in $V$. radiata and $H$. vulgare seedlings irrigated with sewage wastewater of Jazan and Ahd-Almsareha stations before and after treatment with VOCs of $C$. freundii. The levels of $\mathrm{Hg}, \mathrm{Cr}$ and $\mathrm{Al}$ were below detection limit in $V$. radiata seedlings, while $\mathrm{Hg}$, $\mathrm{Cd}$, As and $\mathrm{Cr}$ concentrations were below the detection limit in $H$. vulgare seedlings. Most metals concentrations were decreased in both seedlings irrigated with wastewater treated with VOCs of $C$. freundii in both stations. However, some metals such as $\mathrm{Ag}, \mathrm{Mn}$ and $\mathrm{Mg}$ were found at high concentrations in comparison to control treatment in $V$. radiata seedlings irrigated with treated Jazan wastewater. Likewise, $\mathrm{Pb}, \mathrm{As}, \mathrm{Ag}, \mathrm{Mn}$, $\mathrm{Mg}$ and $\mathrm{Cu}$ levels were higher than those concentrations in control treatment in $V$. radiata seedlings irrigated with treated Ahd-Al-Msareha wastewater. Similarly, $\mathrm{Ag}, \mathrm{Al}$ and $\mathrm{Fe}$ levels in $H$. vulgare seedlings irrigated with treated Jazan wastewater and treated Ahd-AlMsareha wastewater were found at high concentrations in comparison to control treatment.

On the whole, the concentrations of heavy metals in seedlings irrigated with TSE were very low and some of them were below the detection limit. Moreover, the seedlings irrigated with TSE treated with VOCs of C. freundii recorded lower levels of metals than those irrigated with TSE only. These findings are in harmony with Lu et al. [37], who revealed that wastewater does not induce heavy metals pollution in soil and crops, and that the index for heavy metals content is below the critical value of agricultural irrigation water quality standard in China. Also, Biswas et al. [38] discussed the possibility of using municipal wastewater for the irrigation of red Amaranth (Amaranthus tricolor L cv. Surma). The accumulated levels of $\mathrm{Fe}, \mathrm{Mn}, \mathrm{Cu}$, and $\mathrm{Zn}$ were within the safe limits except for the concentration of $\mathrm{Pb}$. At the same time, the depletion of metal concentrations in plant seedlings irrigated with bacteria treated with TSE could be attributed to the transformation of the soluble metal ions of TSE into metal precipitates and hence the bioavailability of metals becomes low. Analogous results were evidenced by Radwan et al. [23], who recorded a clear reduction of copper toxicity against Barley and Mung Bean that were exposed to copper sulfate solution treated with Escherichia coli biogases. They ascribed that to the interaction of bacterial volatile chelators with $\mathrm{Cu}$ ions, transforming them into non-ionic forms. The toxicity of non-ionic copper reduction was attributed to the decline of copper capability to penetrate plant cells.

\section{Conclusions}

Although the application of treated sewage effluents for irrigation purposes has many positive impacts, the heavy metals accumulation in soil and cultivated plants might pose serious problems. The current study highlighted a bioprocess that could be used to minimize heavy metals concentrations in treated sewage effluents using bacterial volatile metabolites. More investigations are necessary to study the efficiency of volatile organic compounds of different microbial strains and to study the effect of the long-term application of sewage effluents treated with microbial VOCs on the physical, chemical and microbiological properties of the treated soil and cultivated crops.

\section{Acknowledgements}

The authors gratefully acknowledge the Dean of Scientific Research at Jazan University for funding this work through the research group project No. JUP $37 / 7 / 000150$. The authors extend their appreciation to all the staff of the Biology Department, Faculty of Science, Jazan University.

\section{Conflict of Interest}

The authors declare no conflict of interest.

\section{References}

1. SAHA M.A., ALAMA A., KHAN M.R. HOQE S. Bacteriological, physical and chemical properties of the Pagla sewage treatment plants' water. Dhaka Univ. J. Biol. Sci, 21 (1), 1, 2012.

2. El-GAYAR K.E. Isolation, identification and characterization of Bacillus subtilis from tap water. Asian journal of microbiology, biotechnology and environmental sciences. 19 (4), 817, 2017. 
3. ABDEL-RAOUF N., AL-HOMAIDAN A.A., IBRAHEEM I.B.M. Microalgae and wastewater treatment. Saudi Journal of Biological Sciences, 19, 257, 2012.

4. NARMADHA D., MARY S.K. Treatment of domestic waste water using natural flocculants. Int. J. Life Sc. Bt \& Pharm. Res, 2012.

5. AL-JASSIM N., ANSARI M. I., HARB M., HONG P. Removal of bacterial contaminants and antibiotic resistance genes by conventional wastewater treatment processes in Saudi Arabia: Is the treated wastewater safe to reuse for agricultural irrigation? Water research, 73, 277, 2015.

6. CYDZIK-KWIATKOWSKA A., ZIELIŃSKA M. Bacterial communities in full-scale wastewater treatment systems, World J Microbiol Biotechnol, 32, 66, 2016.

7. JALAL K.C.A., ALAM Z., MUYIBI S A., JAMAL $P$. Isolation and purification of bacterial strains from treatment plants for effective and efficient bioconversion of domestic wastewater sludge. American Journal of Environmental Sciences. 2 (1), 1, 2006.

8. OSMAN Y.A., DARWEISH D.B., ABDEL-RAHMAN A.M. Bacterial antagonism slowdown secondary sewage treatment. Journal of Environmental Sciences, 43 (3), 465, 2014.

9. AL-BAHRY S.N., PAULSON J.R., AL-MUSHARAFI K. Survival and growth of antibiotic resistant bacteria in treated wastewater and water distribution system and their implication in human health: A review. The international of Arabic journal of antimicrobial agents, 4 (4), 1, 2014.

10. KHAN M.S., SOHAIL M., KHATTAK N.S., SAYED M. Industrial ceramic waste in Pakistan, valuable material for possible applications. Journal of cleaner production, 139, 1520, 2016

11. SAYED M., SHAH L.A., KHAN J.A., SHAH N.S., KHAN H.M., KHAN R.A., KHAN A., KHAN A.M. "Hydroxyl radical based degradation of ciprofloxacin in aqueous solution. Journal of the Chilean Chemical Society, 61 (2), 2949, 2016.

12. SHAH L.A., SAYED M., SIDDIQ M. "Fabrication of Ag and $\mathrm{Au}$ nanoparticles in cross-linked polymer microgels for their comparative catalytic study." Materials SciencePoland, 35 (3), 651, 2017.

13. ALI F., KHAN J.A., SHAH N.S., SAYED M., KHAN H.M. Carbamazepine Degradation by UV and UV-assisted AOPs: Kinetics, Mechanism and Toxicity Investigations." Process Safety and Environmental Protection, 2018.

14. KHAN J., MURTAZA S., FAYAZ A. HASAN M.K., Removal of Acid Yellow 17 Dye by Fenton Oxidation Process." Zeitschrift für Physikalische Chemie, 232 (4), 507, 2018.

15. REHMAN F., SAYED M., KHAN J.A., SHAH L.A., SHAH N.S., KHAN H.M., KHATTAK R. Degradation of Crystal Violet Dye by Fenton and Photo-Fenton Oxidation Processes." Zeitschrift für Physikalische Chemie, 2018.

16. EL BESTAWY E., AL-HEJIN A., AMER R., KASHMERI R.A. Decontamination of domestic wastewater using suspended individual and mixed bacteria in batch system, J Bioremed Biodeg., 2014.

17. SHAKIR E., ZAHRAW Z., AL-OBAIDY A.J. Environmental and health risks associated with reuse of wastewater for irrigation. Egyptian Journal of Petroleum, 26, 95, 2017

18. GAMITO P., ARSENIO A., FALEIRO M.L., BRITO J., BELTRAO J. The influence of waste water treatment on irrigation water quality. In: Anac D., Martin-PrÉvel P. (eds) Improved Crop Quality by Nutrient Management.
Developments in Plant and Soil Sciences, 86. Springer, Dordrecht, 1999.

19. BALKHAIR K.S. Microbial contamination of vegetable crop and soil profile in arid regions under controlled application of domestic wastewater. Saudi Journal of Biological Sciences, 23, 83, 2016.

20. ESSA A.M., EL-GAYAR K.E. Characterization of bacteria from domestic wastewater sewage in Jazan, Saudi Arabia. Egyptian Journal of Experimental Biology (Bot.), 14, 331, 2018.

21. ESSA A.M., AL-ABBOUD M., KHATIB S.K. Metal transformation as a bacterial strategy for heavy metals detoxification. Journal of Basic Microbiology, 2017 [In Press].

22. ESSA A.M., El-SAID E.M., ALI R.M. Biogenic volatile compounds of the activated sludge and application for metal bioremediation. African Journal of Biotechnology 11 (42), 9993, 2012.

23. RADWAN D.M., ESSA A.M., NABIH M.A. Bacterial detoxification of copper and its impacts on germination indices of barley and mung bean, Egyptian Journal of Botany, 56 (3), 817, 2016.

24. AOAC. AOAC official methods of analysis. $15^{\text {th }}$ ed. Association of Official Analytical Chemists, Arlington, Virginia, 84, 1990.

25. TOZE S. Reuse of effluent water-benefits and risks. Agricultural water management 80, 147, 2006.

26. WINPENNY J., HEINZ I., KOO-OSHIMA S., SALGOT M., COLLADO J., HERNANDEZ F., TORRICELLI R. Reutilización del Agua enAgricultura: Beneficios para Todos; FAO, Rome, Italy, 124, 2013.

27. FONSECA A.F., HERPIN U., PAULA A.M., VICTORIA R.L., MELFI A.J. Agricultural use of treated sewage effluents: agronomic and environmental implications and perspectives for Brazil. Scientia Agricola, 64, 194, 2007.

28. MWE. Technical guidelines for the use of treated sanitary wastewater in irrigation for landscaping and agricultural irrigation. Ministry of Water and Electricity, Kingdom of Saudi Arabia, 2006.

29. AL-MUSHARAFI S.K., MAHMOUD I.Y., AL-BARY S.N. Heavy metal contamination from treated sewage effluents. In Proceedings of 11th International Conference on Modelling, Monitoring, and Management of Water Pollution. New Forest, UK: WIT Transactions on Ecology and the Environment, 164, 381, 2012.

30. OLIVERIA S., VON SPERLING M. Reliability analysis of wastewater treatment plants. Water Res., 42, 1182, 2008.

31. ESSA A.M., CREAMER N.J., BROWN N.L., MACASKIE L.E. A new approach to the remediation of heavy metal liquid wastes via off-gases produced by Klebsiella pneumoniae M426. Biotechnology and Bioengineering, 95 (4), 574, 2006.

32. ESSA A.M., MOSTAFA S.M. Bio-mineralization of some heavy metals by cyanobacterial biogas. Egyptian Journal of Botany, 31, 112, 2011.

33. ESSA A.M., KHALLAF M.K. Antimicrobial potentiality of consolidation polymers impregnated with copper nanoparticles. BMC Microbiology, 16, 144, 2016.

34. HANJRA M.A., BLACKWELL J., CARR G., ZHANG F., JACKSON T.M. Wastewater irrigation and environmental health: implications for water governance and public policy. Int. J. Hyg. Environ. Health, 215, 255, 2012.

35. MATHEYARASU R., SESHADRI B., BOLAN N.S., NAIDU R. Abattoir wastewater irrigation increases the availability of nutrients and influences on plant growth and development. Water Air Soil Pollut, 8, 227, 2016. 
36. JARAMILLO M.F., RESTREPO I. Wastewater reuse in agriculture: A Review about its limitations and benefits. Sustainability. 9, 1, 2017.

37. LU S., WANG J., PEI L. Study on the effects of irrigation with reclaimed water on the content and distribution of heavy netals in soil. International Journal of Environmental Research and Public Health, 13 (3), 298, 2016.
38. BISWAS G.C., SARKAR A., RASHID M.H., SHOHAN M.H., ISLAM M., WANG Q. Assessment of the irrigation feasibility of low-cost filtered municipal wastewater for red amaranth (Amaranthus tricolor L cv. Surma). International Soil and Water Conservation Research, 3 (3), 239, 2015. 